\title{
PERSEPSI MASYARAKAT PADA PENDIDIKAN ISLAM DI IAIN PALANGKA RAYA (KAJIAN MOTIVASI MASYARAKAT UNTUK MASUK KE IAIN PALANGKA RAYA)
}

\author{
Zainap Hartati, M.Ag \\ Dosen IAIN Palangka Raya \\ Jl. Yos Sudarso no. 104 palangka Raya
}

\begin{abstract}
ABSTRAK
IAIN Palangkaraya is the only state Islamic university in Central Kalimantan, although there are several public and private universities from different religions in Central Kalimantan. Palangka Raya Municipality has a vision of being a city of education and there are one State and six Private Madrasah Aliyah, the existence of 7 (seven) madrasah is a potential and favorable prospect of student input into IAIN Palangkaraya, however based on the data about students of IAIN Palangka Raya,the graduates of Madrasah Aliyah have not dominated . This reality was also an interesting study, the field data revealed that various factors revealing the public perception and motivation were that parents made IAIN Palangka Raya an institution of higher education for their children. The motivation for giving their children higher education at IAIN Palangka Raya was supported by the availability of their finance, scholarships, and being working students. These conditions were also the attractiveness of IAIN so suitable for the parents that IAIN was a premier choice of education for their children.
\end{abstract}

Key words: implementation of the 2013 Curriculum; Islam-integrated; curriculum evaluation, CIPPO

\section{A. Pendahuluan}

Pendidikan menurut UUSPN 2003 bahwa.: Usaha sadar dan terencana untk mewujudkan suasana belajar dan proses pembelajaran agar peserta didik secara aktif mengembangkan potensi dirinya untuk memiliki kekuatan spiritual keagamaan mengendalikan diri, kepribadan, kecerdasan, akhlak mulia serta keterampilan yang diperlukan dirinya, masyarakat, bangsa dan Negara ${ }^{1}$.

Berdasarkan UUSPN tersebut melalui jalur pendidikan peserta didik mengembangkan potensi dirinya , sehingga dapat berguna bagi masyarakat, bangsa, dan Negara. Mencari dan mengali ilmu pengetahuan dimana saja dapat dilakukan, jenjang yang paling tinggi secara formal melalui Perguruan Tinggi. Dalam ajaran Islam menuntut ilmu merupakan tuntunan dan amanah dari

\footnotetext{
${ }^{1}$ UUSPN. 2003. Bandung : Citra Umbaran.h.86.
} 
Allah SWT, sebagaimana digambarkan dalam surah Al-Alaq ayat 1-5 bermakna bahwa tulis dan baca adalah kunci ilmu pengetahuan, dengan banyak membaca akan diperoleh banyak ilmu yang akan didapat, semakain tinggi ilmu yag digali maka akan semakin mulia dihadapan Allah, dan akan diangkat beberapa derajat.

Pentingnya pendidikan bagi peningkatan kualitas seseorang, sehingga keberadaaan Perguruan tinggi untuk menjadikan sumber daya manusia yang bermutu, berkualitas sesuai tujuan dari Perguruan Tinggi tersebut. Sumber daya manusia menentukan maju atau mundurnya suatu bangsa, dimana ditentukan oleh bermutu atau tidaknya sumber daya manusia (SDM) yang dimiliki bangsa bersangkutan. Sumber daya manusia yang bermutu salah satu di antaranya disebut "intelektual",2. Intelektual yang dimaksud tersebut salah satunya merupakan hasil proses pembelajaran/produk dari pendidikan yang diperoleh pada Perguruan Tinggi. Walaupun demikian Perguruan Tinggi bukan satu-satunya tempat mengolah dan memproses para intelektual namun tetap menjadi tumpuan harapan sebagai penghasil intelektual yang berguna, bagi bangsa, Negara dan agama

Keberhasilan tumbuh dan berkembang suatau lembagaseperti perguruan Tinggi ditentukan juga oleh factor masyarakat. Masyarakat sebagai salah satu factor pendukung yang memiliki andil yang sangat besar bagi berlangsungnya proses pendidikan pada perguruan tinggi. Pandangan masyarakat pada perguruan tinggi mempengaruhi terhadap keberlangsungan suatu proses pendidikan.

2 Disebut intelektual adalah orang yang kreatif, yang selalu berusaha mencari kemungkinan yang baru, mungkin lebih baik dari hasil yang ada. Intelektual merupakan sikap hidup, bukan hanya sekedar pengertian dalam dunia pendidikan, meskipun sebenarnya antara dunia pendidikan yang tinggi dan sikap hidup seorang intelektual terdapa korelasi yang tinggi (semakain banyak pengeahuan seseorang, semakin dia merasa bahwa masih banyak hal-hal yang belum ia ketahui. Lih. Arif Budiman. Kebebasan, Negara, Pembangunan: Kumpulan Tulisan 1965-2005. 2006. Jakarta: Pustaka Alpabet.h.155.. 
Tiap masyarakat meneruskan kebudayaannya dengan beberapa perubahan kepada generasi muda melalui pendidikan, melalui interaksi sosial, dengan demikian pendidikan merupakan sosialisasi. ${ }^{3}$

Dalam kehidupan dimasyarakat tidaklah luput dari polemik pola pikir ataupun persepsi yang menjadi sandaran kehidupan yang dimiliki masyarakat dalam mengenal lingkungan sekitar mereka seperti pandangan mereka terhadap perguruan tinggi yang ada di lingkungannya. Sehingga berhubungan dengan keinginan mereka untuk memberikan pendidikan lebih tinggi pada anakanaknya.

Kota Palangka merupakan salah satu Kota yang ada di Kalimantan tengah memiliki berbagai perguruan tinggi umum maupun agama, seperti halnya IAIN Palangka Raya, sebelumnya IAIN Palangka Raya merupakan Sekolah Tinggi Agama Islam (STAIN) Palangka Raya, kemudian sejak April 2015 berkembang menjadi IAIN Palangka Raya, perkembangan STAIN menjadi IAIN merupakan prosfek yag sangat baik terutama bagi umat Islam yang ada di Kalimantan Tengah maupun luar Kalimantan untuk memperoleh ilmu pengetahuan teutama ilmu - ilmu keislaman.

Keberadaan beberapa Perguruan Tinggi di Kota Palangka Raya hingga 16 (enam belas) buah, negeri maupun swasta, dari berbagai lintas agama menunjukkan kemajemukan kehidupan, dan tantangan bagi Perguruan Tinggi tersebut. Institut Agama Islam Negeri (IAIN) Palangka Raya, sebelumnya IAIN Palangka Raya merupakan Sekolah Tinggi Agama Islam Negeri (STAIN) Palangka Raya, dan sebelumnya lagi adalah Fakultas Tarbiyah IAIN Antasari cabang Palangka Raya, kemudian sejak April 2015 berkembang menjadi IAIN Palangka Raya.

Sebagai satu-satunya perguruan Tinggi Islam negeri, IAIN Palangka Raya memiliki harapan dan peluang yang baik untuk diminat masyarakat muslim sebagai tempat menimba ilmu, namun demikian beberapa kenyataan bahwa:

\footnotetext{
${ }^{3}$ S. Nasution. Sosiologi Pendidikan. Jakarta : Bumi Aksara.2004.h.10
} 
1, Input yang diperoleh lebih dominan berlatar pendidikan umum, jika berlatar pendidikan agama berasal dari luar Kota Palangka Raya ${ }^{4}$.

2. Pengetahuan masyarakat selaku orang tua siswa beranggapan bahwa peruruan tinggi Islam yang ada adalah STAIN, padahal telah berubah menjadi IAIN Palangka Raya 5 .

3. Di IAIN Palangka Raya yang diajarkan atau yang dididik adalah ilmu keguruan, untuk menjadi guru saja ${ }^{6}$.

Berdasarkan kondisi tersebut dan bahwa peneliti tertarik untuk lebih mendalam bagaiman persepsi masyarakat terutama para orang tua yang ada di Kota palangka Raya, tentang pendapat mereka pada pendidikan di IAIN Palangka Raya, pengetahuan apa yang telah mereka peroleh tentang pendidikan Islam yang ada di IAIN Palangka Raya, karena hal ini dapat diperoleh gambaran dan arah tujuan masyarakat pada pendidikan Islam yang ada di IAIN Palangka Raya. Sebagai bahan masukan bagi IAIN dalam upaya memahami pandangan masyarakat pada pendidikan Islam di IAIN Palangka Raya.

Adapun input yang diterima di IAIN Palangka Raya, dalam 2 (dua) tahun terakhir, tahun 2015 mahasiswa yang diterima berjumlah sebanyak 249 (dua ratus empat puluh sembilan) orang dan yang berlatar belakang Madrasah Aliyah (MA) Negeri maupun Swasta adalah 104 (seratus empat) orang dan pada tahun 2016 berjumlah 308 ( tiga ratus delapan) orang dan yang berlatar belakang Madsarah Aliyah (MA) Negeri maupun Swasta 171 (seratus tujuh puluh satu) orang, Input yang berasal dari madrasah lebih didominasi berasal dari luar daerah / luar Kota Palangka Raya ${ }^{7}$.

Kondisi ini juga menjadi tantangan bagi IAIN Palangka Raya, bagaimana menjadikan kampus IAIN sebagai pilihan utama bagi lulusan

\footnotetext{
${ }^{4}$ Pengamatan dan evaluasi peneliti dari ebberapa kelas perkuliahan di IAIN Palangka Raya dari tahun 2004-2011.

${ }^{5}$ Wawancara dengan salah satu orang tua siswa marasah di Kota Palangka Raya, Pebruari 2017.

${ }^{6}$ Wawancara dengan salah satu orang tua siswa marasah di Kota Palangka Raya, Maret 2017.

${ }^{7}$ Data dari Mikwa IAIN Palangka Raya, Juni 2016.
} 
Madrasah Aliyah (MA) negeri maupun swasta baik di luar daerah maupun di wilayah Kota Palangka Raya.

Sebagai Perguruan Tinggi Negeri dengan alih status dari STAIN (Sekolah Tinggi Agama Islam Negeri) menjadi IAIN merupakan tantangan yang cukup berat, seperti : bagaimana menjadikan IAIN tetap dijadikan tumpuan pendidikan bagi masyarakat, bagaimana menjadi IAIN sebagai lembaga yang bermutu di masyarakat dan sebagainya. Kondisi ini menjadikan ketertarikan peneliti untuk mengangkat suatu judul tentang : Persepsi dan motivasi masyarakat pada pendidikan di IAIN Palangka Raya.

Penelitian dilakukan dengan menggunakan pendekatan deskriftip kualitatif, dimana akan dihimpun data dalam bentuk yang wajar, terarah dan dapat dipertanggungjawabkan secara ilmiah, data yang dikumpulkan berupa kata-kata lisan atau tertulis. Bogdam dan Taylor dalam Moleong ${ }^{8}$ menyatakan bahwa metode kualitatif adalah sebuah prosedur yang menghasilkan data deskriptif berupa kata-kata tertulis atau lisan dari orang dan perilaku latar dan individu yang diamati. Lokasi penelitian adalah di Kota Palangka Raya, pelaksanaan penelitian selama 6 bulan dari bulan Mei 2017 sampai dengan Oktober 2017.

Obyek penelitian adalah Persepsi masyarakat terhadap pendidikan di IAIN Palangka Raya. sedangkan subyek penelitian adalah orangtua (ayah/ibu). Penggambilan subyek dilakukan secara purposive sampling, dengan ketentuan :

1. Masyarakat yang dimaksud adalah orang tua yang memiliki anak bersekolah di Madrasah Aliyah baik negeri maupun swasta.

2. Masyarakat yang dimaksud berdomisili di Kota Palangka Raya.

3. Masyarakat yang bersedia untuk dilakukan penelitian.

Setelah data diperoleh sebagaimana ketentuan tersebut, kemudian proses penghimpunan data dilakukan penggalian secara snowball sampling dengan maksud setiap masyarakat yaitu orangtua yang memiliki anak pada

\footnotetext{
${ }^{8}$ Lexy J. Moleong. Metodologi Penelitian Kualitatif. Bandung: PT. Remaja Rosdakarya. 2000. h.
} 3. 
Madrasah Aliyah yang ada di Kota Palangka Raya diperoleh data hingga jenuh (cukup terwakili). Sedangkan teknik pengumpulan dta dengan wawancara, observasi dan dokumentasi.

\section{B. Tinjauan Pustaka dan Pembahasan}

\section{Tinjaun Pustaka}

\section{Pengertian Persepsi}

"Persepsi menurut Kamus Besar Bahasa Indonesia (KBBI) adalah tanggapan (penerimaan) langsung dari sesuatu atau proses seseorang mengetahui beberapa hal melalui panca inderanya".

Menurut M.Alisuf Sabri bahwa persepsi atau tanggapan adalah sesuatu yang pernah kita amati/alami selalu tertinggal jejaknya atau kesannya di dalam jiwa kita. Hal itu dimungkinkan oleh kesanggupan chemis dari jiwa kita. Bekas jejak/kesan yang tertinggal pada kita itu dapat kita timbulkan kembali (reproduksi) sebagai tanggapan ${ }^{\mathbf{1 0}}$,

"Persepsi menurut Abdurrahman Saleh adalah proses yang menggabungkan dan mengorganisasi data-data indera kita (penginderaan) untuk dikembangkan sedemikian rupa sehingga kita dapat menyadari di sekeliling".11.

Menurut Muhammad Said dan Junimar Affan bahwa Persepsi adalah proses yang membeda-bedakan rangsangan yang masuk untuk selanjutnya diberikan maknanya dengan bantuan beberapa faktor. Proses itu dimulai dengan masuknya beberapa ransangan melalui panca indra kita yang jumlahnya sekarang lebih dari lima (panca) rangsangan-rangsangan itu ke pusat-pusat pengelolahan untuk kemudian diberi makna ${ }^{\mathbf{1 2}}$.

\footnotetext{
${ }^{9}$ Pusat Bahasa Departemen Pendidikan Nasional,2002, Kamus Besar Bahasa Indonesia, Jakarta: Balai Pustaka, Ed, 3. Cet 2, h. 863

${ }^{10}$ M. Alisuf Sabri , 2010., Pengantar psikologi umum dan perkembangan, Jakarta: Pedoman ilmu jaya, cet.5,hal 60 .

11 Abdul Rahman Shaleh, 2004, PsikologiSuatu Pengantar dalam Perspektif Islam, Jakarta: Kencana, h.110.

12 Muh.Said dan Junimar Affan, 1990. Psikologi dari zaman ke zaman, Bandung:Jemmars bandung 1990) edisi kedua, hal 45)
} 
Menurut Bagus Takwin bahwa dalam Psikologi, persepsi secara umum merupakan perolehan, penafsiran, pemilihan, dan pengaturan informasi indrawi. Persepsi sosial dapat diartikan sebagai proses perolehan, penafsiran, pemilihan, dan pengaturan informasi indrawi tentang orang lain. Apa yang diperoleh, ditafsirkan, dipilih dan diatur adalah informasi indrawi dari lingkungan sosial. ${ }^{\mathbf{1 3}}$

Persepsi merupakan proses yang berlangsung pada diri sendiri untuk mengetahui dan mengevaluasi orang lain. Dengan proses itu, akan membentuk sebuah kesan tentang orang lain atau sesuatu. Kesan yang dibentuk didasarkan pada informasi yang tersedia di lingkungan, sikap terdahulu tentang rangsangan-rangsangan yang relevan. Lingkungan interaksi seseorang baik yang bersifat fisik maupun lingkungan sosial.

\section{Aspek Persepsi dan Faktor}

Beberapa aspek yang dapat mempengaruhi proses persepsi, aspek persepsi menurut McDowwell \& Newel yaitu Kognisi dan Afeksi 1) Kognisi, 2) Afeksi. $^{14}$

Persepsi dalam prosesnya itu dipengaruhi oleh beberapa faktor yang mem-buat proses persepsi itu tumbuh. Menurut Sarlito W.Sarwono bahwa perbedaan persepsi dapat disebabkan oleh hal-hal di bawah ini ${ }^{\mathbf{1 5}}$ :

1) Perhatian

Biasanya kita tidak menangkap seluruh rangsangan yang ada di sekitar kita sekaligus, tetapi kita memfokuskan perhatian kita pada perhatian kita pada suatu objek atau dua objek saja. Perbedaan fokus antara satu orang dengan orang lainnya, menyebabakan perbedaan persepsi antara mereka.

Setiap persepsi adalah harapan seseorang akan rangsangan yang akan timbul. Misalnya, pada seorang pelari yang siap di garis "star" terdapat set

13 Bagus Takwin, "Persepsi Sosial mengenali dan mengerti orang lain", dalam Sarlito W. Sarwono dan Eko A. Meinarno (ed.), Psikologi Sosial 2011,, Salemba : Humanika, hal 24.

14 Bagus Takwin, "Persepsi sosial mengenali dan mengerti orang lain", dalam Sarlito W. Sarwono dan Eko A. Meinarno (ed.), PSIKOLOGI SOSIAL .2011. Salemba: Humanika. h.26. 9,hal.45-46

${ }^{5}$ Sarlito W.Sarwono. 2003. Pengantar Umum Psikologi. Jakarta : Bulan Bintang. cet 
bahwa akan terdengar bunyi pistol di saat mana ia harus mulai berlari, perbedaan set dapat menyebabkan perbedaan persepsi

3) Kebutuhan

Kebutuhan-kebutuhan sesaat maupun yang menetap pada diri seseorang, orang tersebut akan mempengaruhi persepsi. Dengan demikian, kebutuhan-kebutuhan yang berbeda akan menyebabkan pula perbedaan persepsi.

4) Sistem nilai

Sistem nilai yang berlaku dalam suatu masyarakat berpengaruh pula terhadap persepsi. Suatu eksperimen di Amerika serikat (Bruner dan Godman, 1947, Carter dan Schooler, 1949) menunjukan bahwa anak-anak yangberasal dari keluarga miskin mempersepsikan mata uang logam lebih besar dari pada ukuran yang sebenarnya. Gejala ini ternyata tidak terdapat pada anak-anak yang berasal dari keluarga kaya.

5) Ciri kepribadian

Ciri kepribadian akan mempengaruhi pula persepsi seperti dua orang yang bekerja di kantor yang sama berada di bawah pengawas satu orang atasan, orang yang pemalu dan orang yang tinggi kepercayaaan dirinya akan berbeda dalam mempersepsikan atasannya.

Menurut Walgito agar stimulus dapat dipersepsi, maka stimulus harus cukup kuat, stimulus harus melampaui ambang batas stimulus, yaitu kekuatan stimulus yang minimal tetapi sudah dapat menimbulkan kesadaran, sudah dapat dipersepsi oleh individu. ${ }^{\mathbf{1 6}}$

Sholeh (2009:128) menjelaskan persepsi lebih bersifat psikologis daripada merupakan proses penginderaan saja maka ada beberapa faktor yang mempengaruhi: ${ }^{17}$

1. Perhatian yang selektif, individu memusatkan perhatiannya pada rangsang-rangsang tertentu saja.

\footnotetext{
${ }^{16}$ Walgito, Bimo. 2003. Psikologi Sosial. Yogyakarta: C.V Andi Offset. H. 55.

17 Shaleh, Abdul Rahman. 2009. Psikologi Suatu Pengantar Dalam Perspektif Islam. Jakarta: Kencana.h.128.
} 
2. Ciri-ciri rangsang, rangsang yang bergerak diantara rangsang yang diam akan lebih menarik perhatian.

3. Nilai dan kebutuhan individu

4. Pengalaman dahulu, pengalaman terdahulu sangat mempengaruhi bagaimana seseorang mempersepsi dunianya.

Adanya faktor-faktor tersebut menimbulkan perbedaan persepsi yang dimunculkan, baik dari perhatian, kebutuhan, sistem nilai dan ciri kepribadian. Setiap persepsi orang perorang berbeda-beda cara memberikan tanggapan karena apa yang dilihatnya belum tentu sama dengan fakta yang sebenarnya, karenanya banyak faktor yang mempengaruhi.

\section{Hakikat Motivasi}

Motivasi berasal dari kata motif (motive), berasal dari akar kata bahasa latin movere, yang kemudian menjadi motin; artinya gerak atau dorongan untuk bergerak. Jadi motif merupakan daya dorong, daya gerak, atau penyebab seseorang melakukan berbagai perbuatan dengan tujuan tertentu. $^{18}$

Sedangkan menurut beberapa ahli :

1. Purwanto berpendapat "motivasi adalah pendorong suatu usaha yang disadari untuk mempengaruhi tingkah laku seseorang agar tergerak untuk bertindak melakukan sesuatu sehingga mencapai hasil atau tujuan tertentu". ${ }^{19}$

2. Hamzah B.Uno bahwa :"motivasi adalah dorongan yang terdapat dalam diri seseorang untuk berusaha mengadakan perubahan tingkah laku yang lebih baik dalam memenuhi kebutuhannya”, ${ }^{20}$

3. Sardiman berpendapat bahwa : "motivasi dapat juga dikatakan serangkaian usaha untuk menyediakan kondisi-kondisi tertentu, sehingga seseorang mau dan ingin melakukan sesuatu".21

${ }^{18}$ Abd. Rachman Abror, Psikologi Pendidikan (Yogyakarta : Tiara Wacana, 1999, h. 144.

${ }^{19}$ Purwanto, Drs. M. Ngalim. (1993). Psikologi Pendidikan. Bandung: PT Remaja Rosdakarya.h. 71.

${ }^{20}$ Uno, Hamzah B. (2012). Teori motivasi dan pengukurannya. Jakarta: Bumi Aksara.h.3 
Selanjutnya menurut Mc.Donald, motivasi adalah perubahan energi dalam diri seseorang yang ditandai dengan munculnya "feeling" dan didahului dengan tanggapan terhadap adanya tujuan. Dari pengertian yang dikemukakan Mc. Donald ini mengandung tiga elemen penting.

a, Bahwa motivasi itu mengawali terjadinya perubahan energi pada diri setiap individu manusia. Perkembangan motivasi akan membawa beberapa perubahan energi di dalam sistem "neurophysiological" yang ada pada organisme manusia. Karena menyangkut perubahan energi manusia (walaupun motivasi itu muncul dalam diri manusia), penampakkannya akan menyangkut kegiatan fisik manusia.

b. Motivasi ditandai dengan munculnya, rasa/feeling, afeksi seseorang. Dalam hal ini motivasi relevan dengan persoalan-persoalan kejiwaan, afeksi dan emosi yang dapat menentukan tingkah-laku manusia

c. Motivasi dirangsang karena adanya tujuan. Jadi, motivasi dalam hal ini sebenarnya merupakan respon dari suatu aksi, yakni tujuan. Motivasi memang muncul dari dalam diri manusia, tetapi kemunculannya karena terangsang/terdorong oleh adanya unsur lain, dalam hal ini adalah tujuan. Tujuan ini akan menyangkut masalah kebutuhan". ${ }^{22}$

Berdasarkan beberapa pendapat diatas dapat bahwa motivasi adalah tenaga pendorong atau penarik yang menyebabkan adanya perilaku seseorang ke arah suatu tujuan tertentu agar memiliki kemauan untuk bertindak atau berbuat terhadap sesuatu perbuatan yang akan dilakukan.

Keberadaan motivasi pada seseorang atau manusia akan memberi pengaruh pada perilaku seseorang, namun tergantung seberapa besar motivasi tersebut mampu mengerakkan dan membangkitkan motivasi seseorang untuk berbuat atau berperilaku.

Menurut Daulay bahwa beberapa psikologi ada yang membagi motivasi menjadi 2 (dua) yaitu : 1.Motivasi instrinsik, adalah motivasi yang berasal dari

${ }^{21}$ Sardiman A. M. (2012). Interaksi dan Motivasi Belajar Mengajar. Jakarta: Rajawali.h.75

${ }^{22}$ Sardiman, Interaksi dan Motivasi Belajar-Mengajar, (Jakarta: PT RajaGrafindo Persada, 2000), h. 71-72 
diri seseorang itu sendiri tanpa dirangsang dari luar.2 Motivasi ekstrinsik, yaitu motivasi yang datang karena adanya perangsang dari luar. ${ }^{23}$

Kedua jenis motivasi ini saling isi mengisi sehingga memunculkan perilaku/tindakan seseorang untuk melakukan suatu perbuatan. Contoh motivasi instrinsik misal seseorang ingin melanjutkan pendidikan pada jenjang yang lebih tinggi, pendididikan sebelumnya adalah Madrasah Aliyah (MA) atau yang sederajat seperti Sekolah Menangah Atas (SMA) atau Sekolah Mengah Kejuruan (SMK), kemudian berusaha mencari informasi tentang keberadaan perguruan tinggi tersebut (instrinsik), setelah diketahui tentang keberadaan Perguruan Tinggi tersebut, baik melalui brosur maupun informasi langsung maupun tidak langsung. Keinginan juga muncul dari ajakan atau informasi dan informasi yang diperoleh, untuk mengajak ataupun menyampaikan informasi dengan cepat, tepat dan baik (ekstrrinsik), semakin kuat keinginan seseorang untuk melanjutkan pendidikan pada jenjang yang lebih tinggi.

Berdasarkan contoh tersebut keingin dari dalam diri seseorang didukung dan dipacu oleh rangsangan dari luar, hal ini menunjukkan bahwa motivasi instrinsik di dorong oleh motivasi ekstrinsik, sehingga mampu mendorong keinginan yang dapat diwujudkan pada upaya keinginan dan akan masuk / melanjutkan pendidikan pada jenjang yang lebih tinggi.

Selanjutnya faktor-faktor yang mempengaruhi motivasi dapat di golongkan menjadi dua golongan saja yaitu faktor internal dan faktor eksternal. a. Faktor internal : 1) Faktor pendidikan, 2) Faktor pekerjaan (waktu dan kesempatan), 3) Faktor minat..

\section{b. Faktor Eksternal}

Faktor eksternal dapat dikelompokkan menjadi 3 (tiga) yaitu: faktor keluarga, faktor sekolah (lembaga pendidikan) dan faktor masyarakat. Semua faktor eksternal ini berada di luar diri seseorang yang dapat menimbulkan rangsangan dari dalam diri individu.

\footnotetext{
${ }^{23}$ Nurussakinah Daulay. 2014. Pengantar Psikologi dan Pandangan Al-Q ur'an Tentang Psikologi. Jakarta : Prenademedia.h. 156.
} 
Persepsi dikaitkan dengan motivasi, tentu masyarakat akan memberikan persepsi yang berbeda-beda tentang apa yang dialaminya. Karena setiap orang itu memiliki cara pandang sendiri-sendiri dalam sesuatu hal yang dialami, sehingga motivasi masing-masing orang itu dipengaruhi oleh persepsi mereka sendiri-sendiri. Kemudian persepsi orang tua (masyarakat) tentang Pendidikan Islam di IAIN Palangka Raya juga berbeda-beda. Dengan demikian secara tidak langsung motivasi mereka untuk menguliahkan anaknya ke Perguruan Tinggi IAIN Palangka Raya juga berbeda antara masyarakat yang satu dengan yang lainnya.

\section{Hakikat Pendidikan Islam}

Menurut Ngalim Purwanto bahwa sebelum kita tinjau lebih lanjut apa yang di maksud dengan pendidikan, terlebih dahulu perlu kiranya diterangkan dua istilah yang hampir sama bentuknya, yaitu paedagogie (pendidikan) dan paedagogiek (ilmu pendidikan). Pedagogik atau ilmu pendidikan adalah ilmu pengetahuan yang menyelidiki, merenungkan tentang gejala-gejala perbuatan mendidik ${ }^{24}$.

Menurut Zahara Idris bahwa Mendidik dan pendidikan adalah 2 (dua) hal yang saling berkaitan dari segi bahasa, tetapi kalau kita mendidik berarti kita melakukan suatu kegiatan tindakan. Kegiatan mendidik menunjukan adanya yang mendidik di satu pihak dan yang dididik di lain pihak",25 . Pendidikan diistilahkan juga dengan paedagogik yang merupakan suatu aktivitas dalam upaya emmberikan pengetahuan dari pendidik kepada peserta didik.

Sedangkan pendidikan dalam konteks Islam yaitu pendidikan Islam diistilah-kan juga dengan tarbiyah, ta'lim, ta'dib, riyadhah, irsyad dan tadris. Namun demikian yang banyak digunakan adalah kata Tarbiyah. Tarbiyah diartikan sebagai "proses transformasi ilmu pengetahua dari pendidik (rabbani) kepada peserta didik agar ia memiliki sikap dan

\footnotetext{
${ }^{24}$ M. Ngalim Purwanto, 2000. Ilmu pendidikan Teoritis dan Praktis, Bandung: Remadja Karya, hal.11.

${ }^{25}$ Zahara Idris. 2008. Dasar-dasar Pendidikan, Bandung: Angkasa. hal. 9
} 
semangat yang tinggi dalam memahami dan menyadari kehidupannya, sehingga terbentuk ketakwaan, budi pekerti yang luhur ${ }^{26}$.

Konsep pendidikan secara umum dengan pendidikan Islam memiliki makna pemberian pengetahuan dari peserta didik kepada terdidik, namun dalam keislaman berhubungan dengan dunia dan akherat.

\section{Tanggung Jawab Orangtua sebagai Masyarakat Terhadap Pendidikan Anak}

Orangtua merupakan guru yang pertama dan utama bagi anak-anak mereka, karena pada saat lahir ke dunia manusia mengenal dan mendapat didikan dari kedua orangtuanya, yaitu ayah dan ibu. Ikatan ayah dan ibu serta anak adalah ikatan dalam satu keluarga (ikatan sedarah). Orang Tua adalah sebuah komponen kecil yang terdiri dari suami istri atau bapak ibu yang tinggal bersama anak, yang mana fungsinya tidak hanya sebagai ayah dan ibu saja melainkan juga sebagai orang tua yang bertanggung jawab terhadap pendidikan, pengajaran, dan perkembangan perilaku serta akhlak anak $^{27}$. Al-Qur'an menjelaskan juga akan tanggung jawab orangtua pada anak-anaknya, tersirat pada Firman Allah SWT Q.S. At-Tahrim : 4. Konteks ayat ini, menunjukkan akan tanggung jawab terhadap anggota keluarga, yaitu tanggungjawab orangtua (sebagai penangungjawab keluarga) untuk memelihara diri sendiir maupun anggota kelaurganya (anak-anaknya). Makna "memelihara keluarga" yang berarti kewajiban untuk menjaga. Salah satu sisi penjagaan yang sangat utama dan pertama melalui lingkungan keluarga, berbagai cara dan upaya yang dapat dilakukan, seperti melalui pendidikan, dengan pendidikan akan diperoleh penjagaan keluarga dari api neraka.

Keluarga adalah kelompok sosial yang terdiri atas dua orang atau lebih yang mempunyai ikatan darah, perkawinan, atau adopsi. Dengan demikian, dapat diambil suatu intisari pengertian keluarga yaitu: (1) keluarga adalah kelompok sosial terkecil yang umumnya terdiri dari ayah,

\footnotetext{
${ }^{26}$ Abdul Mujib dan Jusuf Mudzakiir.. 2006. Ilmu Pendidikan Islam. Jakarta: Kencana.hal.12-13.

${ }^{27}$ Fajri, Em Zul dan Ratu Aprilia Senja. tth. Kamus Lengkap Bahasa Indonesia. Difa Publisher.h.602.
} 
ibu, dan anak.(2) hubungan sosial diantara keluarga relative tetap yang didasarkan pada ikatan darah, perkawinan atau adopsi. (3) hubungan antar keluarga dijiwai oleh susunan afeksi dan rasa tanggung jawab. (4) fungsi keluarga adalah memulihkan, merawat,dan melindungi anak dalam rangka sosiolisasi agar mereka mampu mengendalikan diri dan berjiwa sosial ${ }^{28}$.

Keterbatasan orangtua dalam melaksanakan tanggungjawab pendidikan pada anak-anaknya dapat di limpahkan kepada orang lain, yaitu melalui lembaga pendidikan lainnya, baik formal maupun informal. Secara formal melalui kelembagaan yaitu pada jenjang dasar dari mulai Pendidikan Anak usia Dini (PAUD), Taman Kanak-Kanak (TK), Sekolah dasar (SD) atau sederajat hingga Perguruan Tinggi.

Adapun peranan orantua tersebut antara lain, yaitu: a. Peranan keluarga atau orang tua dalam pendidikan jasmani dan kesehatan bagi anakanak. b. Peranan keluarga atau orangtua dalam pendidikan akal.c. Peranan keluarga atau orang tua dalam pendidikan agama bagi anak-anak.d. Peranan keluarga atau orang tua dalam pendidikan psikologikal dan emosi.e. Peranan keluarga atau orangtua dalam pendidikan akhlak bagi anak-anak.f. Peranan keluarga atau orangtua dalam pendidikan sosial anak-anak.

Menjalankan tugas dan tanggung jawab tersebut diatas. Kelurga atau orangtua tidak dapat dijalankan secara maksimal tanpa adanya kerjasama dari berabgai pihak, kerjasama dengan masyarakat, kerjasama dengan lembaga.sekolah dna kerjasama dengan pemerintah slekau pemangku kebijakan.

\section{Perguruan Tinggi Islam Negeri}

Perguruan tinggi bukanlah sekedar lanjutan dari Sekolah Lanjutan Atas, tetapi merupakan suatu yang hakiki dan taraf pendidikan tinggi itu sesuai tuntunan pendidikan tinggi ${ }^{29}$. Dunia perguruan tinggi merupakan dunia ilmu pengetahuan dengan tujuan utama pendidikan tinggi adalah

${ }^{28}$ Anwar Hafid, dkk. 2013. Konsep Dasar Ilmu Pendidikan. PT Alfabeta: Bandung. hal. 44

${ }^{29}$ Burhanuddin Salam. 2004. Cara Belajar Yang Sukses di Perguruan Tinggi. Jakarta : Rineka Cipta. Hal.1. 
mengembangkan dan menyebarkan ilmu pengetahuan, teknologi dan kebudayaan dengan proses belajar mengajar, penelitian dan pengabdian kepada masyarakat ${ }^{30}$.

Tujuan pendidikan pada perguruan tinggi sebagai berikut $: 1$. Menyiapkan peserta didik menjadi anggota masyarakat yang memilki kemampuan akademik dan/atau professional yang dapat menerapkan, mengembangkan, dan/atau memperkaya khazanah ilmu pengetahuan, teknologi, dan/atau kesenian. 2. Mengembangkan dan menyebarluaskan ilmu pengetahuan, teknologi, dan / atau kesenian serta mengupayakan penggunaannya untuk taraf kehidupan masyarakat dan memperkaya kebudayaan nasional ${ }^{31}$.

IAIN sebagai bagian dari sistem perguruan tinggi melalui perguruan tinggi Islam yang ada di Indonesia. IAIN memiliki peran yaitu: (a) IAIN merupakan salah satu jalur terbesar bagi mobilitas pendidikan kaum santri, (b) IAIN memberikan persfektif modern dan liberal dalam kajian-kajian keislaman dan ketiga: banyaknya alumni IAIN yang menjadi guru atau kyai di pesantren ${ }^{32}$.

\section{Pembahasan}

\section{Gambaran Umum Kota Palangka Raya}

Kota Palangka Raya secara resmi ditetapkan sebagai Ibu Kota Provinsi Kalimantan Tengah pada tanggal 17 Juli 1957, dengan kondisi fisik kota yang belum ada, hanya berupa kampung yaitu Kampung Pahandut, yang terletak di tepi Sungai Kahayan. Secara geografis, Kota Palangka Raya terletak pada posisi : $113^{03} 0^{0}-14^{0} 07^{0}$ Bujur Timur dan 1035' - 20240 Lintang Selatan.

Kota Palangka Raya mempunyai luas wilayah 2.678,51 Km² (267.851 Ha) dibagi ke dalam 5 (lima) Kecamatan yaitu: (1) Kecamatan Pahandut, (2) Sabangau, (3) Jekan Raya, (4) Bukit Batu dan (5) Rakumpit dengan luas

\footnotetext{
${ }^{30}$ R. Eko Indrajit dan R. Djokopranoto. 2006. Manajemen Perguruan Tinggi Modern. Yogyakarta: Andi.hal.37.

${ }^{31}$ Peraturan Pemerintah RI Nomor 60 tahun 1999 tentang Pendidikan Tinggi. Pasal 2.

${ }^{32}$ Fuad Jabali dan Jamhari. 2002. IAIN Modernisasi Islam di Indonesia. Jakarta: Logos wacana Ilmu. hal.108.
} 
masing-masing $117,25 \mathrm{Km}^{2}, 583,50 \mathrm{Km}^{2}, 352,62 \mathrm{Km}^{2}, 572 \mathrm{Km}^{2}$ dan $1.053,14$ $\mathrm{Km}^{2}$.

Mengacu pada Rencana Pembangunan Jangka Menengah Daerah (RPJMD) Kota Palangka Raya Tahun 2013-2018, maka Visi Pembangunan Daerah Kota Palangka Raya adalah “Terwujudnya Kota Palangka Raya sebagai kota pendidikan, jasa, dan wisata berkualitas, tertata dan berwawasan lingkungan menuju masyarakat sejahtera sesuai falsafah Huma Betang,,33.

Sejalan dengan visi pembangunan daerah Kota Palangka Raya antara lain sebagai Kota Pendidikan, berbagai jenjang pendidikan terdapat di Kota Palangka Raya, dari jenjang Pendidikan Anak Usia Dini (PAUD), Sekolah Dasar (SD) dan Madrasah Ibtidaiyah (MI), Sekolah Lanjutan Pertama (SMP dan Madrasah Tsanawiyah / MTs), Sekolah Lanjutan Atas (SMA, SMK dan Madrasah Aliyah / MA) hingga Perguruan Tinggi (PT) baik negeri maupun swasta.

Di Kawasan pintu masuk Sanaman Mentikei bertuliskan jargon Kota Palangka Raya bertuliskan "Kawasan Pendidikan”. Pada Kawasan tersebut berdampingan berbagai jenjang lembaga pendidikan. Pada saat pagi menjelang kedatangan pelajar memadatkan jalan-jalan disekitar lembaga pendidikan yang ada, demikian juga pada saat siang menjelang kepulangan pelajar tersebut. Kondisi ini memperkuat visi Kota sebagai Kota pendidikan.

Secara demografi Kota Palangka Raya terdiri dari 5 (lima) kecamatan yang dibagi dalam 30 (tiga puluh) Kelurahan yaitu : 1. Kecamatan Pahandut, dibagi dalam 6 (enam) kelurahan ; 2. Kecamatan Jekan Raya, dibagi dalam 4 (empat) kelurahan ; 3. Kecamatan Sabangau, dibagi dalam 6 (enam) kelurahan ; 4. Kecamatan Bukit Batu, dibagi dalam 7 (tujuh) kelurahan dan 5. Kecamatan Rakumpit, dibagi dalam 7 (tujuh) kelurahan.

\footnotetext{
33 (https://rianfakhriansyah.wordpress.com./2017/03/29/profil.kotapalangka-raya/ (dionlinekan pada tanggal 25 Oktober 2017).
} 
Kota Palangka Raya dengan 5 (lima) kecamatan menempatkan keberadaan beberapa Madrasah Aliyah (MA) baik negeri maupun swasta. Adapun data tentang Madsarah Aliyah yang ada di Kota Palangka Raya yang tersebar berjumlah 7 (tujuh) Madrasah sebagai berikut: 1. Madrasah Aliyah Swasta (MAS) Darul Ulum, Jalan DR. Murjani Gang Sari 45, Kecamatan Pahandut Kota Palangka Raya; 2. Madrasah Aliyah Swasta (MAS) Hidayatul Insan, Jalan Sulawesi No. 76 Palangka Raya; 3. Madrasah Aliyah Swasta (MAS) Miftahul Jannah, Jalan Pahandut Seberang Kecamatan Pahandut. Palangka Raya. 4. Madrasah Aliyah Swasta (MAS) Muslimat NU, Jalan Pilau No. 41 Palangka Raya, Kecamatan Pahandut, Palangka Raya; 5. Madrasah Aliyah Swasta (MAS) Raudhatul Jannah, Jalan Surung No.1 RT.1 RW 2 Sebangau, Kecamatan Sebangau, Palangka Raya; 6. Madrasah Aliyah Negeri (MAN) Model Palangka Raya / MAN Kota Palangka Raya, Jalan Cilik Riwut Km. 4.5 Kecamatan Jekan Raya. Palangka Raya dan 7. Madrasah Aliyah Swasta (MAS) Annur, Jalan Mahakam No. 31 Kecamatan Jekan Raya. Palangka Raya.

Kota Palangka Raya memiliki 7 (tujuh) Madrasah Aliyah, dan hanya ada 1 (satu) Madrasah Aliyah (MA) yang berstatus negeri, yaitu MAN Model / MAN Kota Palangka Raya beralamatkan di Jalan Cilik Riwut Km 4,5 Palangka Raya. Kendati demikian, keberadaan 6 (enam) Madrasah Aliyah Swasta (MAS) dilingkungan masyarakat Kota Palangka Raya dan sekitarnya masih tetap menjadi harapan atau tempat menitipkan anak-anak mereka untuk meyekolahkannya / menuntut ilmu di lingkungan madrasah tersebut.

Beberapa Madrasah Aliyah (MA) yang memiliki status Madrasah dengan kurikulum pesantren yaitu MAS Hidayatul Insan Jalan Sulawesi, MAS Darul Ulum Jalan DR. Murjani dan MAS Raudhatul Jannah Jalan Surung. Khusus MAS Raudhatul Jannah Jalan Surung merupakan lembaga pesantren sekaligus lembaga panti asuhan tempat menampung anak-anak yatim/yatim piatu.

Selanjutnya data tentang kepala madrasah Aliyah yang tersebar di 7 (tujuh) tempat sebagaimana Tabel berikut 
Daftar Nama Kepala Madrasah Aliyah (MA) di Kota Palangka Raya ${ }^{34}$

\begin{tabular}{|c|l|l|c|}
\hline No & Nama Madrasah Aliyah & Nama Kepala Madrsaah & $\begin{array}{l}\text { Sejak } \\
\text { Tahun }\end{array}$ \\
\hline 1 & MAN Model / Kota & H. Idayani, M.Pd.I & 2017 \\
\hline 2 & MAS Hidayatul Insan & H. Gunawan, S.Pd & 2003 \\
\hline 3 & MAS Darul Ulum & Drs. Mardaya, M.Pd & 2012 \\
\hline 4 & MAS Muslimat NU & Mashudi, M.Pd & 2006 \\
\hline 5 & MAS Miftahul Jannah & Isra A. Hady, S.Pd & 2005 \\
\hline 6 & MAS Raudhatul Jannah & Rahmah, S.Pd & 2008 \\
\hline 7 & MAS Annur & Syamsul Huda, S.Pd & 2011 \\
\hline
\end{tabular}

Sumber : Data yang diolah, 2017

Sebagaimana Tabel 2 di atas, terlihat bahwa kepemimpinan Madrasah Aliyah (MA) yang cukup lama adalah MAS Hidayatul Insan sejak tahun 2003 hingga sekarang, sedangkan kepemimpinan Madrasah Aliyah (MA) yang mulai tahun 2017 adalah MAN Model / MAN Kota Palangka Raya.

Adapun data tentang jumlah siswa yang tersebar di 7 (tujuh) Madrasah Aliyah di Kota Palangka Raya sebagaimana Tabel berikut;

Data Siswa Kelas XII di MA se Kota Palangka Raya ${ }^{35}$

\begin{tabular}{|c|l|c|c|}
\hline No & Nama Madrasah & Jumlah siswa & Tahun Berdiri \\
\hline 1 & MAN Kota / Model & 308 siswa & 1975 \\
\hline 2 & MAS Hidayatul Insan & 43 siswa & 2003 \\
\hline 3 & MAS Darul Ulum & 213 siswa & 1998 \\
\hline 4 & MAS Muslimat NU & 81 siswa & 2000 \\
\hline 5 & MAS Miftahul Jannah & 110 siswa & 2005 \\
\hline 6 & MAS Raudhatul Jannah & 41 siswa & 2008 \\
\hline 7 & MAS Annur & 13 siswa & 2006 \\
\hline & Jumlah & $\mathbf{8 0 9}$ siswa & \\
\hline
\end{tabular}

Sumber : Data yang diolah, 2017

\footnotetext{
${ }^{34}$ Data hasil penelitian bulan Juni s.d September 2017

${ }^{35}$ Data hasil penelitian bulan Juni s.d September 2017
} 
Sebagaimana Tabel di atas, terlihat bahwa keberadaan Madrasah Aliyah (MA) yang lebih dahulu adalah MAN Model / MAN Kota Palangka Raya (tahun 1975), sedangkan yang terbaru adalah MAS Raudhatul Jannah (tahun 2008). Sedangkan dari segi jumlah siswa Kelas XII yang terbanyak adalah MAN Model / MAN Kota sebanyak 308 orang dan jumlah siswa yang paling sedikit adalah MAS Annur sebanyak 13 orang siswa.

Sedangkan jumlah siswa kelas XII yang ada di Madrasah Aliyah di Kota Palangka Raya secara keseluruhan sebanyak 809 siswa. Jumlah ini merupakan potensi yang dapat menjadikan IAIN sebagai tempat studi lanjut bagi siswa-siswi tersebut. Keberadaan siswa MA yang tersebar di kota Palangka Raya merupakan kontribusi yang memungkinkan menjadi mahasiswa pada IAIN Palangka Raya. Sehingga IAIN Palangka Raya menjadi pilihan utama atau tujuan utama untuk memperoleh atau mengali keilmuan terutama ilmu pendidikan Islam, melalui berbagai prodi yang ada.

\section{Persepsi masyarakat pada pendidikan Islam di IAIN Palangka Raya}

Berdasarkan wawancara dengan beberapa orangtua dan juga siswa sebagai wawancara dengan MM bahwa :

Saya mengetahui itu IAIN, adanya di Jalan G.Obos... itu saya ketahui dari dosen yang ngajar di sana, eee..... ibu siapa tuh lupa saya. IAIN itu tempat untuk belajar agama Islam atau untuk kuliah agama Islam. Untuk jadi guru atau pendidik ${ }^{36}$.

Selanjutnya menurut orangtua $\mathrm{M}$ yang memiliki anak HN bahwa.

IAIN tahu.. tuk orang kuliah agama, jadi guru. Informasi tentangn IAIN dari kawan. IAIN tuk menuntut ilmu-ilmu agama .. baguslah.. ${ }^{37}$

Selanjutnya menurut N orangtua dari NA bahwa:

Saya mengetahui IAIN Palangka Raya, ia.... dari televisi siaran-siaran nya tentang IAIN .. apalagi saat bulan Ramadhan ada ucapan-ucapan selamat puas . Selamat lebaran . nah.. ada dari IAIN Palangka Raya. Dari teman juga

36 Wawancara dengan orangtua MM yang memiliki anak di MAS Muslimat NU dan saat ini duduk di kelas IPS bernama SN. Agustus 2017.

37 Wawancara dengan M memiliki anak sekolah di MAS Muslimat NU dan saat ini duduk di kelas XII IPA. Agustus 2017 
ada memberitahu saya juga dari dosen yang mengajar di sana. Pendidikan yang ada di IAIN ada syariah, Tarbiyah, FUAD, PGMI, Pendidikan Fisika juga Biologi. Ada pendidikan agama Islam dan umum. Bagus.... ${ }^{38}$

Selanjutnya menurut K orangtua dari RW bahwa:

Tentang IAIN saya mengetahui, dari teman yang anaknya juga telah kuliah di sana jurusan Syariah. Di IAIN itu pendidikan agama yang saya tahu. Baguslah pendidikan di IAIN sekarang.. gedungnya sudah bagus-bagus... banyak lagi mahasiswanya sekarang ini. Satu-satunya universitas berlandaskan agama. $^{39}$

Beberapa hasil wawancara menunjukkan bahwa orangtua mengetahui keberadaan tentang IAIN Palangka Raya, baik melalui dosen IAIN, dari teman maupun media televisi dan sebagainya. IAIN menurut pandangan mereka / orangtua bahwa IAIN merupakan tempat untuk menuntut ilmu agama Islam .

Selanjutnya wawancara dengan AR orangtua dari S bahwa.

IAIN Palangka Raya saya mengetahuinya, info awal saya ketahui dari teman saya. di IAIN banyak pendidikan yang ditawarkan seperti pendidikan Tarbiyah dan Keguruan, hukum Islam, agama dan dakwah yaitu FUAD. FUAD itu kepanjangannya adalah Fakultas Ushuluddin Adab dan Dakwah. Kemudian ada Pendidikan umum seperti Ekonomi Syariah, Akutansi, Perbankan dan lainnya. Baguslah pendidikan yang ada di IAN ada umum dan agama. Alhamdulillah di Palangka Raya. ${ }^{40}$

Selanjutnya menurut SA orangtua SF bahwa:

Kami mengetahui tentang IAIN Palangka Raya, ada di jalan G. Obos satu kompleks dengan Masjid Raya Darussalam Palangka Raya. Kami sering shalat Jum'at di Masjid Raya Darussalam nah.. secara tidak langsung pasti melihat kampus IAIN ... . Banyak gedungnya dan Bagus-bagus sekarang

${ }^{38}$ Wawancara dengan $\mathrm{N}$ memiliki anak di MAN Kota Palangka Raya, jurusan agama. Agustus 2017.

${ }^{39}$ Wawancara dengan K memiliki anak di MAN Kota Palangka Raya jurusan MIPA 1, Agustus 2017.

${ }^{40}$ Wawancara dengan AR yang memiliki anak S sekolah di MAS Darul Ulum Palangka Raya, Agustus 2017. 
gedungnya ... Anak saya ada juga yang kuliah di IAIN, di Fakultas Tarbiyah, jadi banyak juga tahu tentang IAIN dari anak kami. ${ }^{\mathbf{4 1}}$

Persepsi masyarakat terhadap keberadaan kampus IAIN Palangka Raya: pengetahuan mereka tentang IAIN Palangka Raya sangat baik. IAIN dipandang sebagai tempat menimba ilmu-ilmu agama juga ilmu umum. Informasi tentang IAIN Palangka Raya diperoleh dari berbagai informasi : a.Dari teman atau sabahat. b.Dari dosen yang bersangkutan melalui sosialisasi yang dilaksanakan oleh IAIN Palangka Raya.c.Dari anak yang telah kuliah di IAIN. Dan d. Dari pengamatan langsung.

Masyarakat yaitu orangtua siswa mengetahui IAIN Palangka Raya sebagai Perguruan Tinggi Islam Negeri yang ada di Kota Palangka Raya, namun demikian pengetahuan tentang keberadaan IAIN Palangka Raya sebagai tempat untuk memberikan keilmuan agama Islam mereka peroleh dari berbagai info, melalui teman, saudara, dosen IAIN Palangka Raya juga media televisi.

Adanya perhatian akan adanya perguruan tinggi Islam menunjukkan bahwa pengamatan dan perhatian orangtua sebagai masyarakat cukup dibanggakan, terlebih bagi keberlanjutan pendidikan anak-anak mereka. Perhatian yang ditunjukkan oleh orangtua sebagai masyarakat menunjukkan perannya bagi eksistensi proses transpormasi pendidikan pada generasi selanjutnya.

Perbedaan Persepsi yang dimunculkan orangtua pada pendidikan Islam di IAIN palangka Raya, seirama dengan pendapat Sarlito W.Sarwono bahwa perbedaan persepsi dapat disebabkan oleh hal-hal di bawah ini ${ }^{\mathbf{4 2}}$ : 1) Perhatian, Biasanya kita tidak menangkap seluruh rangsangan yang ada di sekitar kita sekaligus, tetapi kita memfokuskan perhatian kita pada perhatian kita pada suatu objek atau dua objek saja. Perbedaan fokus antara satu orang dengan orang lainnya, menyebabakan perbedaan persepsi antara mereka. Setiap

${ }^{41}$ Wawancara dengan SA memiliki anak SF sekolah di MAS Darul Ulum jurusan Ilmu Keagamaan, Agustus 2017.

${ }^{42}$ Sarlito W.Sarwono. 2003. Pengantar Umum Psikologi. Jakarta : Bulan Bintang. cet 9, hal.45-46 
persepsi adalah harapan seseorang akan rangsangan yang akan timbul. Misalnya, pada seorang pelari yang siap di garis "star" terdapat set bahwa akan terdengar bunyi pistol di saat mana ia harus mulai berlari, perbedaan set dapat menyebabkan perbedaan persepsi. 2) Kebutuhan, Kebutuhan-kebutuhan sesaat maupun yang menetap pada diri seseorang, orang tersebut akan mempengaruhi persepsi. Dengan demikian, kebutuhan-kebutuhan yang berbeda akan menyebabkan pula perbedaan persepsi. 3) Sistem nilai Sistem nilai yang berlaku dalam suatu masyarakat berpengaruh pula terhadap persepsi. Suatu eksperimen di Amerika serikat (Bruner dan Godman, 1947, Carter dan Schooler, 1949) menunjukan bahwa anak-anak yangberasal dari keluarga miskin mempersepsikan mata uang logam lebih besar dari pada ukuran yang sebenarnya. Gejala ini ternyata tidak terdapat pada anak-anak yang berasal dari keluarga kaya. 4) Ciri kepribadian, Ciri kepribadian akan mempengaruhi pula persepsi seperti dua orang yang bekerja di kantor yang sama berada di bawah pengawas satu orang atasan, orang yang pemalu dan orang yang tinggi kepercayaaan dirinya akan berbeda dalam mempersepsikan atasannya.

Berdasarkan data lapangan, persepsi yang dimunculkan orangtua pada pendidikan Islam di IAIN di adanya perhatian dan kebutuhan. Perhatian diperlihatkan dengan pengamatan yang dilakukan baik langsung maupun tidak langsung. Bertanya tentang keberadaan IAIN Palangka Raya maupun melalui keberadaan anak mereka yang telah menjadi mahasiswa di IAIN Palangka Raya.

Kemudian perhatian yang memunculkan persepsi orangtua, adanya upaya yang dilakukan dengan mengamati maupun bertanya, secara langsung (melalui dosen IAIN Palangka Raya) maupun melalui anak sebelumnya yang telah menajdi mahasiswa di IAIN Palangka Raya.

Proses transformasi pendidikan yang diharapkan pada masyarkaat yang memiliki perhatian pada pendidikan tinggi seperti IAIN Palangka Raya akan memberikan peluang dan harapan adanya keinginan untuk memberikan pendidikan yang lebih tinggi pada anak-anak mereka. 


\section{Motivasi masyarakat pada Pendidikan Islam di IAIN Palangka Raya}

Berbagai pendapat tentang IAIN Palangka Raya yang dikemukakan oleh masyarakat/orangtua, sehingga akan diperoleh informasi / harapan mereka terhadap keberadaan Perguruan Tinggi Islam (IAIN Palangka Raya), sebagaimana wawancara berikut:

Wawancara dengan MM memiliki anak SN bahwa.

Anak saya mau saya kuliahkan jua, maunya ke IAIN pang.... tapi maukah anak tu jadi guru... lihat ja nanti mau kemana setelah tamat di Madrasah ini. Mudahanan ja mau kuliah. Saya suka ja anak lanjutkan kuliah. Kuliah di IAIN banyak nanti dia mendapat ilmu-ilmu agama, tapi tergantung anak kami dan orangtua mendorong ja. ${ }^{43}$

Selanjutnya menurut SN bahwa. "Ulun mau ja sekolah di IAIN, mana ja mau .... asal mama abah mau mengongkosinya. Jar sidin ke IAIN ayu ai ulun ke IAIN. Kada jauh jua ke IAIN. Ulun pakai kendaraan jua. Kada masalah kalau kuliah ke jalan G.obos sana." ${ }^{44}$

Menurut menurut $\mathrm{M}$ yang memiliki anak HN bahwa:

Mau saja anak kuliah tapi... bagaimana ya... saya mau dia kuliah sambil kerja. Kalau saja tanpa kerja sulit saya. Maunya ke Muhammadiyah saja biar sambil kerja .. Nah di Kampus IAIN kuliahnya pagi kalau di Universitas Muhammadiyah sore dan malam bisa pagi kuliah. Jadi anak saya kuliah sambil kerja. ${ }^{45}$

Selanjunya menurut HN anak dari M bahwa

Ulun mau ja kuliah, tapi disuruh orangtua kuliah sambil kerja. Setahu ulun di Muhammadiyah bisa kuliah smabil kerja. Pagi kerja nah.. sore atau malam kerja. Di IAIN dan Muhammadiyah sama ja kuliah agama jua dan untuk jadi guru jua. ${ }^{46}$

\footnotetext{
${ }^{43}$ Wawancara dengan orangtua MM yang memiliki anak di Madrasah Muslimat NU dan saat ini duduk di kelas IPS bernama SN. Agustus 2017

${ }^{44}$ Wawancara dengan SN anak dari MM, Agustus 2018

${ }^{45}$ Wawancara dengan M memiliki anak sekolah di MAS Muslimat NU dan saat ini duduk di kelas XII IPA. Agustus 2017

${ }^{46}$ Wawancara dengan HN siswa MAS Muslimat NU, Agustus 2017.
} 
Pendapat selanjutnya menurut $\mathrm{N}$ yang memiliki anak NA bahwa.

Anak saya mau saya kuliahkan di IAIN... terserahnya mau ke Syariah, atau kependidikan ... yang penting kuliah.. insya Allah saya bisa mengongkosi-nya asal anaknya mau kuliah ${ }^{47}$

Selanjutnya wawancara dengan NA

Mau... mau kuliah IAIN.. mama abah setuju ja. Maunya ke Tarbiyah aja. Jadi guru lah.... tapi taulah nanti kedepan jadi guru atau apa lah....(sambil tertawa. $^{48}$

Selanjutnya menurut AR yang memiliki anak S bahwa.

Mau sekali anak saya kuliah, mudahan ada ongkos saya mengkuliahkan anak ke IAIN lah... IAIN saja karena banyak ilmu-ilmu agama yang bisa dia peroleh di sana, kalau nanti saya tak punya uang untuk ongkosi dia kuliah... ya... tak apalah... mudahan anaknya mau ja kuliah... aku mau dia lanjut kuliah ke IAIN saja, apalagi di MAS Darul Ulum guru-guru dan kepala Madrasahnya juga banyak lulusan atau alumni IAIN.. bagus kan. Berarti pendidikan di IAIN bermutu. ${ }^{49}$

Selanjutnya wawancara dengan S menurutnya.

Ulun mau ja kuliah kalau ada dananya untuk kuliah, maunya kuliah di FUAD, mau bisa siaran di RRI, kawan ulun kuliah di FUAD nah... sambil siaran di RRI... kayanya sambil kuliah dapat juga pekerjaan. Tapi kalau orangtua tak ada biaya mau apa ulun. Mudahan ada sidin biaya untuk emngkuliahan ulun. Doakan ulun bu bisa kuliah.. Apalagi guru-guru disini memberi motivasi kami setelah tamat di Madrasah ini lanjutkan kuliah ke IAIN Palangka Raya ${ }^{50}$

Selanjutnya menurut kepala MAS Darul Ulum bahwa

\footnotetext{
${ }^{47}$ Wawancara dengan N memiliki anak di MAN Kota Palangka Raya, jurusan agama. Agustus 2017.

${ }^{48}$ Wawancara dengan NA, Agustus 2017.

${ }^{49}$ Wawancara dengan AR yang emmiliki anak S sekolah di MAS Darul Ulum Palangka Raya, Agustus 2017.

${ }^{50}$ Wawancara dengan S anak AR, Agustus 2017.
} 
Kami disini selalu memotivasi anak-anak setelah tamat di MAS Darul Ulum agar bisa melanjutkan kuliah ke IAIN, dan memang banyak anak-anak kami yang lulus atau tamat, kemudian mereka melanjutkan ke IAIN Palangka Raya, bahkan melalui jalur beasiswa, kami mengupayakan mereka yang tidak mampu untuk bisa kuliah mendapatkan beasiswa bidik misi atau beasiswa apa saja yang bisa memberika kesempatan anak-anak kami untuk dapat studi lanjut. Guru-guru disini rata-rata adalah alumni dari IAIN bahkan ada yang sedang kuliah S2 di IAIN Palangka Raya pada Prodi Magister Manajemen Pendidikan Islam (MPI) saat ini sedang proses menyusun laporan penelitian tesis. $^{51}$

Apa yang diungkapkan oleh kepala MAS Darul Ulum peneliti bertemu dan menyapa beberapa orang guru MAS Darul Ulum yang merupakan alumni STAIN Palangka Raya (dulu STAIN sekarang IAIN Palangka Raya) dan guru MAS Darul Ulun yang berstatus mahasiswa S2 pada Prodi MPI (sedang menyusun laporan penelitian tesis). ${ }^{\mathbf{5 2}}$

Motivasi selanjutnya sebagaimana pendapat $\mathrm{K}$ yang memiliki anak RW bahwa:

Anak saya nanti harus lanjut kuliah, jangan berhenti. Sayang.. saya masih bisa ongkosi dia kuliah sampai selesai.. insya Allah. Insya Allah maunya ke IAIN Palangka Raya, tapi bagus juga anda jurusan Psikologi di IAIN ditambah lagi. Maunya saya karena saya suka yang ilmu-ilmu Psikologi. ${ }^{53}$

Selanjutnya menurut RW:

Ulun terserah mama ja. Jar sidin ulun kuliah di IAIN ulun kuliah di sana .. atau jar sidin kuliah di Jawa ulun ayu jua. Yang penting kuliah. ${ }^{\mathbf{5 4}}$

Pendapat SA yang memiliki anak SF bahwa:

\footnotetext{
${ }^{51}$ Wawancara dengan Kepala MAS Darul Ulum , Agustus 2017

${ }^{52}$ Pengamatan dilokasi MAS Darul Ulum, Agustus 2017.

${ }^{53}$ Wawancara dengan K memiliki anak di MAN Kota Palangka Raya jurusan MIPA 1, Agustus 2017.

${ }^{54}$ Wawancara dengan RW, Agustus 2017.
} 
Kalau anak kami selesai di MA ini maunya lanjutkan kuliah.. ke IAIN saja ambil jurusan agama di IAIN, seperti kakanya di Tarbiyah, tapi mudahan ada biayanya untuk kuliah, pekerjaan kami swasta saja. Mudahan bisa mengongkosi kakanakan kuliah, tapi mudahan ada beasiswa dari IAIN untuk anak kami kuliah, kakanya kemaren dapat beasiswa, mudahan adingnya ni juga bisa dapat beasiswa. ${ }^{\mathbf{5 5}}$

Apa yang diungkapkan oleh SF tentang keinginan anaknya agar melanjutkan kuliah jika memiliki biaya karena saudara sebelumnya juga kuliah, hal wajar diungkapkan oleh SA, dengan melihat kondisi lingkungan tempat tinggal dan juga pengahasilan pekerjaan orangtua sebagai swasta, dagang kecil-kecilan sekitar MAS Darul Ulum, sehingga berharap adanya bantuan atau beasiswa dari IAIN Palangka Raya. ${ }^{56}$

Selanjutnya menurut SF anak dari SA:

Ulun memang handak kuliah ke IAIN kaya orang jua ... tapi terserah abah mama saja, kalau memang ada biayanya, kalau kadada biaya kada papa aja ulun kada kuliah... kan kaka ulun sudah ada yang kuliah. Kasian kalau ulun kuliah, akan memberatkan beban orangtua. Tapi kalau kadada biaya maunya ulun kerja sambil kuliah. ${ }^{57}$

Berdasarkan wawancara tersebut orangtua memiliki keinginan untuk dapat menyekolahkan anak-anak mereka setelah selesai atau tamat di Madrasah Aliyah, dengan harapan memperoleh panambahan ilmu, demikian juga keinginan untuk menempatkan pendidikan pada IAIN Palangka Raya agar men-dapatkan ilmu agama.

Informasi selanjutnya dari siswa MAS Annur bahwa mereka menginginkan bisa melanjutkan kuliah sebagaimana perwakilan dari siswa tersebut bahwa

${ }^{55}$ Wawancara dengan SA memiliki anak SF sekolah di MAS Darul Ulum jurusan Ilmu Keagamaan, Agustus 2017.

\footnotetext{
${ }^{56}$ Pengamatan lokasi tempat tinggal orangtua/SA. Agustus 2017.

${ }^{57}$ Wawancara dengan SF anak SA, Agustus 2017
} 
Ulun pengen setelah lulus di MAS Annur lanjut ke IAIN, tapi menurut orangtua kerja sambil kuliah... nah di IAIN bisakah bu ulun kuliah sambil kerja?, kalau tidak bisa ulun ke Muhammadiyah ja di sana pagi ulun kerja lalu sore dan malam kuliah, di IAIN adakah yang seperti itu. Jar mama ulun mun bisa begitu bisa ja kuliah di IAIN kerja sambil kuliah ${ }^{\mathbf{5 8}}$.

Selanjutnya diungkapkan oleh guru M salah satu guru MAS Annur bahwa

siswa disini sekolah sekedarnya saja bu, ini juga satu kelas jurusan IPS, tahun sebelumnya tidak ada yang masuk ke IAIN semuanya masuk ke Universitas Muhammadiyah, karena mereka rata-rata anak-anak yang orangtua kurang mampu, sehingga jika mereka harus kuliah mereka kuliah sambil bekerja. Nah... di Universitas Muhammadiyah yang bisa sistem pagi kerja sore sampai malam kuliah. Kalau di IAIN ada seperti itu mungkin mereka ada jua yang mau kuliah ke IAIN Palangka Raya. ${ }^{59}$

Pada saat peneliti mengamati kelas di MAS Annur yang hanya memiliki satu ruang kelas untuk kelas XII jurusan IPS (hanya satu jurusan saja), tidak ada seorangpun siswa yang berada di ruangan, padahal waktu masih menunjuk-kan jam aktif belajar. Kemudian Guru M memanggil para siswa kelas XII tersebut untuk masuk ke kelas, setelah dipanggil ruangan kelas XII memiliki siswa yang siap belajar. ${ }^{\mathbf{6 0}}$

Berdasarkan pengamatan yang dilakukan, ungkapan yang dikemukakan oleh orangtua, mayoritas pekerjaan adalah swasta, bukan pegawai negeri, sebagaimana berikut :

1. MAS Raudhatul Jannah merupakan Madrasah Aliyah juga Panti Asuhan, siswa pada lembaga ini adalah anak-anak panti asuha, tidak emmiliki orantua ibu atau ayah, sehingga mereka tergantung pada wali murid yang mengayomi mereka, sedangkan orantua yang masih ada bekerja untuk makan sehari-hari. ${ }^{61}$

\footnotetext{
${ }^{58}$ Wawancara dengan MW siswa MAS Annur, September 2017

${ }^{59}$ Wawancara dengan Guru MAS Annur Palangka Raya, September 2017

${ }^{60}$ Pengamatan di Lokasi Mas Annur, September 2017.

${ }^{61}$ Observasi yang dilakukan peneliti, September 2017
} 
2. MAS Miftahul Jannah merupakan Madrasah Aliyah yang terletak di pinggiran sungai Kahyan yang berada di Pahandut Sebrang, pekerjaan orangyan mayoritas adalah pencari ikan (nelayan), sehingga biaya untuk pendidikan anak pada jenjang yang klebih tinggi belaum atau tidak tersedia, demikian juga lokasi madrasah yang sederhana (bahan kayu). ${ }^{62}$

3. MAS Annur, madrasah ini berada di lingkungan yayasan Annur di lingkungan Masjid Annur Kota Palangka Raya, pekerjaan orangtua mayoritas swasta. ${ }^{63}$

Motivasi siswa untuk melanjutkan kuliah atau studi lanjut perlu dukungan finansial dari orangtua, untuk kelancaran studi kelak, sehingga tanpa dukungan biaya pendidikan, siswa yang akan studi lanjut ke Perguruan Tinggi harus kuliah samabil bekerja sebagaimana yang di alami oleh siswa MAS Annur Palangka Raya.

Pengetahuan masyarakat atas keberadaan IAIN Palangka Raya di Kota Palangka Raya, berpeluang untuk memberikan harapan menjadikan IAIN sebagai tempat anak-anak mereka para orangtua untuk menjadi lembaga pendidikan tinggi sebagai kelanjutan pendidikan setelah pendidikan di jenjang Madrasah Aliyah, sebagaimana hasil wawancara pada bab sebelumnya, adanya keinginan para orangtua untuk memberikan pendidikan yang lebih tinggi pada anak-anak mereka seperti melanjutkan kuliah di IAIN Palangka Raya. Namun demikian harapan sebgai motivasi yang dimunculkan para orangtua juga tidak terlepas dari keinginan anak-anak mereka, apakah akan melanjutkan pendidikan hingga perguruan tingga ataukah tidak.

Kondisi ini menunjukkan bahwa adanya motivasi orangtua untuk menitipkan pendidikan anaknya pada IAIN Palangka Raya. Namun

\footnotetext{
${ }^{62}$ Observasi yang dilakukan peneliti, September 2017

${ }^{63}$ Observasi yang dilakukan peneliti, September 2017. Berdasarkan wawancara dengan guru MAS Annur : bahwa anak di Mas Annur ini adalah anak yang kurang mampu, dimana orangtua bekerja seharian penuh tetapi hanya cukup untuk keperluan sehari-hari, sehingga sebagaimana alumni sebelumnya mereka masuk keliah ke Muhammadiyah, karena Muhammadiyah kuliah bisa pada malam hari, dan para mahasiwa pada siang ssmapi sore bekerja.
} 
demikian motivasi yang muncul dominan ditentukan oleh ekstrinsik, yaitu motivasi dari luar diri seperti

1. Ada keinginan untuk pendidikan anak ke IAIN Palangka Raya , bagi orangtua yang tersedia dana untuk pendidikan lebih tinggi;

2. Adanya keinginan untuk pendidikan tinggi bagi anak jika tersedia dana/biaya;

3. Orangtua berkeinginan adanya beasiswa yang diberikan pada anak-anak mereka, hal ini dikemukakan oleh orangtua yang bekerja swasta, sehingga memerlukan biaya yang lebih jika anak melanjutkan pendidikan yang lebih tinggi/ pada perguruan tinggi seperti IAIN Palangka Raya.

4. Orangtua berharap anak dapat melanjutkan pendidikan pada perguruan tinggi tetapi sambil bekerja, hal ini dikemukakan oleh orangtua agar biaya pendidikan dapat tercukupi, karena keterbatasan dana/biaya yang dimiliki.

Motivasi tersebut yang dimunculkan oleh orantua yang memiliki anak di Madrasah Aliyah (MA ) yang tersebar di Kota Palangka Raya, dominan di pada point 2 dan 3.

Adanya motivasi orangtua dengan point 2 dan 3 menunjukkan bahwa keinginan untuk masuk melanjutkan pendidikan Islam di IAIN Palangka Raya disediakan adanya kondisi-kondisi tertentu yaitu adanya dana dan beasiswa. Hal ini sejalan dengan pendapat Sardiman berpendapat bahwa : "motivasi dapat juga dikatakan serangkaian usaha untuk menyediakan kondisi-kondisi tertentu, sehingga seseorang mau dan ingin melakukan sesuatu". ${ }^{64}$

Motivasi orangtua untuk pendidikan anaknya, dengan point ke 4 yaitu kuliah sambil bekerja, dengan keterbatasan dana/biaya bahkan tidak adanya biaya untuk pendidikan anak ke jenjang lebih tinggi berdampak pada pencarian penyediaan pendidikan tinggi yang meluangkan wkatu pembelajaran pada saat sore hingga malam hari, waktu pagi sampai

${ }^{64}$ Sardiman A. M. Interaksi dan Motivasi ....h.75 
dengan siang adalah berusaha/bekerja. Menurut Mc.Donald, motivasi adalah perubahan energi dalam diri seseorang yang ditandai dengan munculnya "feeling" dan didahului dengan tanggapan terhadap adanya tujuan. Dari pengertian yang dikemukakan Mc. Donald ini mengandung tiga elemen penting.

a, Bahwa motivasi itu mengawali terjadinya perubahan energi pada diri setiap individu manusia. Perkembangan motivasi akan membawa beberapa perubahan energi di dalam sistem "neurophysiological" yang ada pada organisme manusia. Karena menyangkut perubahan energi manusia (walaupun motivasi itu muncul dalam diri manusia), penampakkannya akan menyangkut kegiatan fisik manusia.

d. Motivasi ditandai dengan munculnya, rasa/feeling, afeksi seseorang. Dalam hal ini motivasi relevan dengan persoalan-persoalan kejiwaan, afeksi dan emosi yang dapat menentukan tingkah-laku manusia

e. Motivasi dirangsang karena adanya tujuan. Jadi, motivasi dalam hal ini sebenarnya merupakan respon dari suatu aksi, yakni tujuan. Motivasi memang muncul dari dalam diri manusia, tetapi kemunculannya karena terangsang/terdorong oleh adanya unsur lain, dalam hal ini adalah tujuan. Tujuan ini akan menyangkut masalah kebutuhan". 65

Sebagaimana pendapat Mc. Donald tentang elemen yang terkandung dari motivasi bahkan keinginan untuk menmberikan pendidikan yang lebih tinggi pada anak ada dengan adanya "feeling" orangtua : pendidikan anak lebih baik dari mereka, namun keterbatasan biaya/dana yang membatasi gerak langkah untuk melanjutkan keinginan pendidikan yang lebih tinggi pada anak-anak mereka. Dorongan yang diberikan untuk mencapai keinginan dnegan "bekerja", sebagai upaya membantu pembiayaan kuliah anak-anak mereka atau adanya beasiswa yang disedian oleh perguruan tinggi.

Kedua keinginan tersebut baik dari orangtua maupun anak sebagai pelaksana untuk melanjutkan pendidikan lebih tinggi juga didukung oleh

${ }^{65}$ Sardiman, Interaksi ..., h. 71-72 
dana yang dimiliki, sehingga keinginan untuk studi lanjut perlu didukung dengan adanya beasiswa bagi siswa yang kurang mampu.

Tanggung jawab pendidikan merupakan tanggungjawab bersama, karena semua komponen masyarakat orangtua, guru lembaga maupun pemerintah turut bertanggung jawab dalam mencerdaskan kehidupan bangsa sebagaimana diamanahkan dalam UU Sisdiknas Nomor 20 tahun 2003 bahwa:

Bahwa sistem pendidikan nasional harus mampu menjamin pemerataan kesempatan pendidikan, peningkatan mutu serta relevansi dan efisiensi manajemen pendidikan untuk menghadapi tantangan sesuai dengan tuntunan perubahan kehidpan lokal, nasional, dan global sehingga perlu dilakukan pem-baharuan pendidikan secara terencana, terarah dan berkesinambungan. ${ }^{\mathbf{6 6}}$

Berdasarkan hal tersebut diatas, bahwa setiap warga negara berhak untuk mendapatkan pendidikan (pemerataan), sehingga peran serta semua pihak untuk tercapainya kecerdasan pada anak bangsa adalah tanggungjawab bersama sesuai dengan tupoksinya masing-masing.

Berbagai beasiswa telah disediakan untuk mensukseskan kecapaian pemerataan pendidikan, beasiswa mahasiswa berprestasi, beasiswa bidik isi dan sebagainya merupakan salah satu upaya yang telah dilakukan pemerintah secara kelembagaan untuk membantu masyarakat dalam mencapai keberhasilan dalam pendidikan.

Pendidikan yang baik akan memberikan dan menggangkat derajat dan harkat sesorang sebagaimana firman Allah SWT dalam Al-Qur'an Surah alMujadilah ayat 11.

Pendidikan bertujuan untuk mengangkat derajat seseorang, sehingga diberikan kemulian oleh Allah SWT beberapa derajat. Masyarakat yang mem-percayakan pendidikan bagi anak-anak mereka pada suatu lembaga pendidikan, dimana melalui Lembaga pendidikan baik umum maupun agama, swasta maupun negeri, sesuai dengan pendidikan nasional berfungsi

${ }^{66}$ Departemen agama RI. 2007. Undang-Undang Sisdiknas No. 20 tahun 2003.h. 1 
mengembangkan kemampuan dan membentuk watak serta peradaban bangsa, serta bertujuan untuk berkembangnya potensi peserta didik agar menjadi manusia yang beriman dan bertakwa kepada Tuhan Yang Maha Esa, berakhlak mulia, sehat, berilmu, cakap, kreatif, mandiri dan menjadi warga negara yang demokratis serta bertanggung jawab. Demikian juga dinyatakan dalam Al-Qur'an Allah SWT berfirman Q.S. AZ-Zumar : 9.

Lembaga pendidikan mempunyai tujuan untuk mengembangkan semua potensi yang dimiliki manusia yaitu, mulai dari tahapan kognisi, yakni pengetahuan dan pemahaman mahasiswa terhadap ajaran agama dan pengetahuan umum, untuk selanjutnya dilanjutkan dengan tahapan afeksi, yaitu terjadinya proses internalisasi ajaran, nilai agama dan pengetahuan ke dalam diri mahasiswa, dalam arti menghayati dan menyakininya.

Melalui tahapan afeksi tersebut diharapkan dapat tumbuh motivasi dalam diri siswa dan bergerak untuk mengamalkan dan mentaati ajaran, nilai agama dan pengetahuan (tahapan Psikomotorik) yang telah diinternalisasikan dalam dirinya. Dengan demikian, akan terbentuk manusia Indonesia yang bertakwa dan berakhlak mulia.

Secara teoritis bahwa Tujuan pendidikan pada Perguruan Tinggi sebagai berikut: 1) Menyiapkan peserta didik menjadi anggota masyarakat yang memilki kemampuan akademik dan/atau profesional yang dapat menerapkan, mengembangkan, dan/atau memperkaya khazanah ilmu pengetahuan, teknologi, dan/atau kesenian. 2) Mengembangkan dan menyebarluaskan ilmu pengetahuan, teknologi, dan/atau kesenian serta mengupayakan penggunaannya untuk taraf kehidupan masyarakat dan memperkaya kebudayaan nasional ${ }^{67}$.

Pendidikan memiliki peranan yang sangat penting untuk menunjang aktivitas dalam hidup dan kehidupan manusia, karena pada dasarnya manusia dalam melaksanakan kehidupannya tidak lepas dari pendidikan (ilmu penge-tahuan). Sebab, pendidikan berfungsi sebagai meningkatkan kualitas manusia itu sendiri. Sejalan dengan UU No 20 tahun 2003, pasal 6 ayat 5 bahwa : Setiap warga negara berhak mendapatkan kesempatan

\footnotetext{
${ }^{67}$ Peraturan Pemerintah RI Nomor 60 tahun 1999 tentang Pendidikan Tinggi. Pasal 2.
} 
meningkatkan pendidikan sepanjang hayat". ${ }^{68}$. Tanggungjawab pendidikan bagi bangsa Indonesia merupakan tanggungjawab bersama, sesuai dengan UU no 20 tahun 2003, sehingga tidak ada lagi rakyat Indonesia yang tidak dapat menikmati pendidikan dengan berbagai alasan : kurang biaya, tidak adanya biaya bahkan tidak tersedia lembaga pendidikan pada wilayah di Indonesia.

\section{Faktor yang mempengaruhi persepsi dan motivasi masyarakat pada pendidikan Islam di IAIN Palangka Raya.}

Pandangan dan motivasi yang diungkapkan oleh para orangtua yang memiliki anak pada pendidikan Madrasah Aliyah di Kota Palangka Raya, tentang keberadaan IAIN Palangka Raya secara umum mengetahui tentang keberadaan IAIN sebagai perguruan Tinggi Agama Islam, sehingga ada motivasi untuk anak-anak mereka kuliah di IAIN Palangka Raya sebagai tempat untuk menimba ilmu-ilmu agama Islam. Namun demikian keinginan tersebut sebagai harapan kedepan yang diinginkan oleh para orangtua kepada anak-anak mereka, juga harapan para orangtua kepada IAIN Palangka Raya.

Sebagaimana pendapat K yang memiliki anak RW bahwa:

Anak saya nanti harus lanjut kuliah, jangan berhenti. Sayang.. saya masih bisa ongkosi dia kuliah sampai selesai.. insya Allah. Insya Allah maunya ke IAIN Palangka Raya, tapi bagus juga anda jurusan Psikologi di IAIN ditambah lagi. Maunya saya karena saya suka yang ilmu-ilmu Psikologi. ${ }^{69}$

Apa yang diungkapkan oleh $\mathrm{K}$ : keinginan untuk pendidikan anaknya pada jenjang lebih tinggi, karena K merupakan lulusan Sarjana S1, sehingga berharap anaknya juga sampai sarjana, sebagaimana yang diungkapkannya

Saya ingin anak-anak saya lanjtkan pendidikannya, kalau bisa lebih tinggi dari saya, terus S2 .. S3 kalau perlu, mudahan saya bisa mengongkosi

${ }^{68}$ Undang-Undang RI no. 20 tahun 2003. Tentang Sistem Pendidikan Nasional.h. 29.

${ }^{69}$ Wawancara dengan K memiliki anak di MAN Kota Palangka Raya jurusan MIPA 1, Agustus 2017. 
atau membiayainya. Bagi saya pendidikan itu sangat penting. Kemana saja anak-anak saya mau kuliah yang penting ada kemauan anaknya. ${ }^{70}$

Menurut MI yang memiliki anak SI bahwa

Saya mau aja menyekolahkan anak ni ke sekolah yang tinggi lagi, seperti kuliah, tapi,,,, bagaaimana dengan dananya, ada ya beasiswa di IAIN Palangka Raya, kalau ada anak mau bisa saja dia kuliah, dengan adanya beasiswa. $^{71}$

Menurut SI : “ ulun mau kuliah... tapi kasiha abah kerjanya siang malam dagang keliling, kadang tengah malam pulang... nah adakah biaya tuk kuliah... mau aja kuliah tapi lihatlah nanti ada apa tidak biaya tuk kuliah". ${ }^{72}$

Berdasarkan pengamatan peneliti, orangtua siswa mengungkapkan pernyataan ini bahkan ada keinginan untuk memberikan pendidikan ke jenjang lebih tinggi pada anaknya asalkan ada biaya, dilihat pekerjaan orangtua adala mencari ikan. Dalam kehidupan sehari-hari adalah berjualan keliling, dan penghasilan yang diperoleh cukup untuk kehidupan seharihari. $^{73}$

Selanjutnya menurut $\mathrm{N}$ yang memiliki anak $\mathrm{NA}^{74}$ bahwa.

Anak saya mau saya kuliahkan di IAIN... terserahnya mau ke Syariah, atau kependidikan ... yang penting kuliah.. insya Allah saya bisa mengongkosinya asal anaknya mau kuliah.

Ungkapan $\mathrm{N}$ menunjukkan kebebasan yang diberikannya pada anaknya dalam menempuh pendidikan yang lebih tinggi, pemilihan keahliannyang akan diikuti diserahkan kepada anaknya, yang paling penting anak mau kuliah. Suatu sikap yang positif memberikan kebebasan anak memilih jalur pendidikan atau keahlian yang dipilih.

Beberapa faktor yang mempengaruhi persepsi dan motivasi masyarakat pada Pendidikan Islam pada IAIN Palangka $\mathrm{R}$ aya sebagaimana beberapa

\footnotetext{
${ }^{70}$ Wawancara dengan K . Agustus 2017.

${ }^{71}$ Wawancara denag MI yang emmilki anak SI di MAS Miftahul Jannah. September 2017

${ }^{72}$ Wawancara dengan SI siswa MAS Miftahul jannah. September 2017.

${ }^{73}$ Observasi peneliti yang dilakukan bulan agustus 2017.

${ }^{74}$ Wawancara dengan N yang memiliki anak di MAN kota Palangka Raya, September
} 2017. 
pernyataan sebelumnya bahwa: 1 . Faktor dari dalam diri anak untuk bersedia melanjutkan studi ke Perguruan Tinggi. 2. Faktor dari luar yaitu adanya dukungan dana maupun persetujuan dari orang tua dan juga motivasi dari kepala Madrasah dan guru setempat.

Motivasi orangtua sebagai masyarakat pada pendidikan Islam di IAIN Palangka Raya dipengaruhi oleh faktor dari dalam diri dan juga luar diri mereka. Keinginan agar anak-anak mereka memperoleh ilmu-ilmu agama lebih dalam merupakan konseksuansi akan motif yang ditimbulkan dari diri orangtua yang menginginkan anak-anaknya menjadi orang yang bergurna. Kemudian benturan biaya dan sebagainya merupakan faktor luar diri masyarakat untuk dapat membiayai anak kuliah pada perguruan tinggi setelah tamat Madrasah Aliyah setempat. Faktor eksternal lebih mendominasi keinginan orangtua untuk memasukkan anak pada pada IAIN Palangka Raya. Motivasi internal akan muncul dan teraktualisasi dengan adanya faktor eksternal.

\section{Penutup}

1. Persepsi masyarakat pada Pendidikan Islam di IAIN Palangka Raya sebagai salah satu perguruan tinggi Islam yang membekali ilmu-ilmu keagamaan Islam.

2. Motivasi masyarakat pada pendidikan di IAIN Palangka Raya, semua orangtua berkeinginan anak mereka melanjutkan kuliah di IAIN Palangka Raya, namun juga terserah pada pilihan anak, jika tersedia dana dan adanya beasiswa.

3. Faktor yang mempengaruhi persepsi dan motivasi pada pendidikan Islam di IAIN Palangka Raya, dipengaruhi oleh faktor eksternal. Motivasi intrinsik yaitu adanya keinginan untuk kuliah bagi anak dan keinginan orangtua agar

4. anak melanjutkan kuliah setelah tamat di Madrasah Aliyah akan teraktualisasikan jika adanya faktor ekstrinsik yaitu adanya dukung ketersediaan dana sehingga, anak kuliah jika ada biaya, kuliah sambil kerja atau adanya beasiswa dari IAIN Palangka Raya. 
5. Sebagai saran: a.)Pemerintah setempat, agar menyediakan atau mengalokasikan dana untuk pen-didikan masyarakat yang kurang mampu. b.) IAIN Palangka Raya, agar lebih banyak menyediakan dana / beasiswa terutama pada Madrasah yang kurang ekonomi sehingga siswa yang berkeinginan unutk kuliah di IAIN Palangka Raya dapat tertampung. c.) Madrasah Aliyah se Kota Palangka Raya, agar mencari terobosan beasiswa bagi siswa yang kurang mampu untuk dapat melanjutkan pendidikan ke Perguruan Tinggi. Juga senantiasa memotivasi siswa untuk studi lanjut hingga Perguruan Tinggi. Dan d) Masyarakat/orangtua, senantiasa memotivasi anak untuk terus belajar hingga Perguruan Tinggi.

\section{Dafatar referensi}

Abdul Rahman. Shaleh. 2009. Psikologi Suatu Pengantar Dalam Perspektif Islam. Jakarta: Kencana.

Abror .Abd. Rachman, 1999. Psikologi Pendidikan. Yogyakarta : Tiara Wacana.

Djaali. 2007. Psikologi Pendidikan. Jakarta: Bumi Aksara.

Daulay. Nurussakinah. 2014. Pengantar Psikologi dan Pandangan AlQur'an Tentang Psikologi. Jakarta : Prenademedia.

Hamzah B . Uno,. 2012. Teori motivasi dan pengukurannya. Jakarta: Bumi Aksara.

Hasan, Langgulung. 2004. Manusia dan Pendidikan (Suatu Analisis Psikologis, Filsafat dan Pendidikan). Jakarta: PT Pustaka Al Husna Baru

Indrajit. R. Eko dan R. Djokopranoto. 2006. Manajemen Perguruan Tinggi Modern.Yogyakarta: Andi.

Jabali, Fuad dan Jamhari. 2002. IAIN Modernisasi Islam di Indonesia. Jakarta : Logos wacana Ilmu.

Kaelan, 2011. Metode Penelitian Kualitatif dalam Filsafat, Paradigma bagi Pengembangan Penelitian Interdisipliner bidang Filsafat, Budaya, Sosial, Semiotika, Sastra, Hukum dan Seni. Yogyakarta : Paradigma. 
E-ISSN : 2580-7056, ISSN : 2580-7064

Pascasarjana IAIN Palangka Raya

Moleong. Lexy J. 2000. Metodologi Penelitian Kualitatif. Bandung: PT. Remaja Rosdakarya.

Mujib. Abdul dan Jusuf Mudzakiir.. 2006. Ilmu Pendidikan Islam. Jakarta: Kencana.

Mustaqim, Abdul. 2005. Menjadi Orang Tua Bijak (Solusi Kreatif Menangani Pelbagai Masalah pada Anak). Bandung: PT Mizan Pustaka

Peraturan Pemerintah RI Nomor 60 tahun 1999 tentang Pendidikan Tinggi. Pasal 2.

Purwanto. M. Ngalim , 2000. Ilmu pendidikan teoritis dan praktis, Bandung: Remadja karya.

Suryabrata, Sumadi, 2012. Metode Penelitian.. Jakarta: Rajawali Press, Ed. $1-23$.

Slameto. 2010. Belajar dan faktor-faktor yang mempengaruhinya. Jakarta: Rineka Cipta.

Salam. Burhanuddin . 2004. Cara Belajar Yang Sukses di Perguruan Tinggi. Jakarta : Rineka Cipta.

Soekanto. Soejono. 2012 , Sosiologi suatu pengantar, Rajawali pres:Jakarta, cet-44.

S. Nasution. 2004. Sosiologi Pendidikan. Jakarta : Bumi Aksara.

Sardiman A. M. 2012. Interaksi dan Motivasi Belajar Mengajar. Jakarta: Rajawali

Undang-Undang RI Nomor 20 tahun 2003. Tentang Sistem Pendidikan Nasional.

Zahara Idris. 2008. Dasar-dasar pendidikan, Bandung: Angkasa. 